\title{
Conjunctival impression cytology: a review
}

\section{WDH Gillan*}

\author{
Department of Optometry, University of Johannesburg, PO Box 524, Auckland Park, 2006 South \\ Africa
}

<wgillan@uj.ac.za>

Received 14 July 2008; revised version accepted 28 September 2008

\section{Conjunctival anatomy}

The conjunctiva is a thin translucent mucous membrane that lines the posterior surfaces of the two eyelids and which reflects forwards onto the anterior surface of the globe of the eye. For ease of description the conjunctiva is divided into three regions: palpebral, bulbar and fornixial conjunctiva, however, all parts of the conjunctiva are continuous. The conjunctiva consists of two layers; the epithelium and the substantia propria $^{1}$. The epithelium has a deep layer consisting of cylindrical cells covered by a number of layers of polyhedral cells with the most superficial cells being flattened while still retaining their nuclei ${ }^{1}$. The surface of the conjunctiva consists of non-keratinizing squamous epithelium with goblet cells interspersed between the epithelial cells. The basal layer of the epithelium presents with hemidesmosomes and tonofilaments and is separated from the substantia propria by a thin basement membrane ${ }^{2}$. Collagen fibrils of connective tissue are found beneath the basement membrane $^{2}$. The thickness of the conjunctival epithelium varies between two and five cells (approximately) ${ }^{2}$.

Goblet cells can be found in all areas of the conjunctiva and they are large, oval or round cells that resemble fat-cells and have flattened nuclei ${ }^{1}$. Goblet cells are more numerous in the caruncle, semilunar folds and fornixial areas ${ }^{2}$. Goblet cells are essentially absent from the limbal conjunctiva ${ }^{2}$. The conjunctival mucosubstance is derived from the goblet cells that exist in the conjunctiva. The cytoplasm of goblet cells is packed with collections of rope-like mucin that is released onto the surface of the conjunctiva ${ }^{2,3}$.

An electron microscopic study ${ }^{4}$ of the surface of the conjunctiva reveals that the epithelium of the conjunctiva has a continuous sheet of cells that have a polygonal shape with a shaggy texture. Randomly distributed among the epithelial cells are the goblet cells. Goblet cells were able to be categorized into small, mature and hypermature cell types ${ }^{4}$. The small goblet cells presented with flat surfaces, elliptical outlines and short microvilli. The mature cells were more globular and were more elevated relative to the surrounding tissue. Hypermature goblet cells were also globular but were without the microvilli. Goblet cells that had discharged their contents were found to have retracted into the surrounding surface tissue leaving a small surface defect that was covered over with time ${ }^{4}$.

\section{Impression cyctology}

"... is the technique of collection of the most superficial layers of the ocular surface by applying different collecting devices (usually filter papers) so that cells adherent to that surface are subsequently removed from the tissue and further processed for a diversity of techniques. It represents therefore a non- or minimally invasive biopsy of, usually, the conjunctiva ${ }^{5} \ldots$... Impression cyctology was first introduced in 1977 when it was noticed that absorbent filters (for example Millipore membrane filter VSWP $0.025 \mu \mathrm{m}$ ) would not only remove mucous secretions from the conjunctival surface but sheets of epithelial cells, which included goblet cells, as well ${ }^{5}$. Once the specimen is obtained the cells are fixed and then stained for analysis ${ }^{5}$.

In general terms conjunctival impression cytology (CIC) involves the following ${ }^{5-11}: 1$. A piece of filter paper is applied to the conjunctival surface for approximately 2-5 seconds. Some authors recommend instilling aneasthetic but the procedure can be carried out without it. 2. The filter paper is removed from the conjunctiva in a peeling motion to ensure maximal collection of surface cells. 3. The cells are fixed by various means. 4 . The cells that are adherent to the filter paper are stained to enhance the visibility of 
the goblet cells with counter staining of the epithelial cells to increase the contrast of the goblet cells. 5. The specimen is examined under a light microscope and various analyses of the visible cells are conducted.

Tissue fixation is a prerequisite to all cell and tissue staining procedures ${ }^{12}$. Fixation is necessary for a number of reasons: to inhibit autolysis and bacterial contamination, prevent solubility of those components that are of interest and provide conditions that will enhance the effects of various biological dyes ${ }^{12}$. Fixatives that are commonly used in CIC are: formaldehyde (formalin), glutaraldehyde, ethanol and methanol $^{12}$. Some authors make use of a spray fixative but do not give specific names ${ }^{9}$.

In CIC staining involves submerging the specimen in a sequence of different dyes. One of the better stains for the demonstration of the presence of carbohydrate derivatives (mucin) in tissues and cells is the Periodic acid-Schiff's reagent (PAS). The reaction that occurs is an oxidation of vicinal glycol groups or their amino or alkylamine derivatives by the periodic acid. This oxidation produces dialdehydes that then react with the Schiff's reagent resulting in a magenta coloration of all cells containing mucin, the goblet cells (and their secretions) in this case ${ }^{12}$. After PAS staining the specimen is then transferred to hematoxylin which acts as a counter-stain to stain the epithelial cell nuclei that are present on the filter paper ${ }^{5}$. Hematoxylin stains cell nuclei a blue-black color resulting in enhanced observation of the epithelial cells that form part of the specimen. Hematoxylin itself is not a stain. It is an oxidation product, haematein (a natural dye), that results in the characteristic coloration of the nuclei ${ }^{13}$.

Various staining protocols have been published in the past ${ }^{16-10}$, however, only one example of a staining protocol is going to be given. The staining protocol presented here is one that is a modified Nelson procedure $^{10,14}$, the following steps are conducted: 1 . Once the specimen has been fixed with a spray fixative it is rinsed in distilled water. 2. The specimen is submerged in periodic acid for 10-15 minutes. 3. Rinse in distilled water. 4. Immerse in Schiff's reagent for 15-20 minutes. 5. Rinse in tap water for 5 minutes. 6. Stain with hematoxylin for 1-2 minutes. 7 . Rinse in tap water. 8. Allow to dry. 9. Mount on microscope slide. At this point in time the specimen is ready to be analyzed under a microscope. An investigation ${ }^{15}$ into various aspects of the CIC procedure (for example: the filter size used, effects of drying, spray versus alcohol fixation and use of double sided tape) showed: 1. That larger pore-sized filters were more effective in picking up cells compared with small pore-sized filters $(0.025 \mu \mathrm{m}$ versus $0.45 \mu \mathrm{m}$ filter sizes). 2 . In CIC air drying has no adverse effects on cytological detail (for typical collection durations). 3. Alcohol fixation was shown to be superior to spray fixation, especially when the specimen is stained using Papanicolaou stain. 4. Staining is inferior (compared to free floating staining) when using double-sided tape to adhere the filter paper to a microscope slide.

\section{Analysis}

A number of different aspects of the CIC specimen can be evaluated using a microscope for analysis of the adherent cells: goblet cell density and morphology $^{7-9,11}$, the nuclear/cytoplasm (N/C) ratio ${ }^{7-8,14}$, nuclear morphology and inclusions ${ }^{7,14}$, colour of the cytoplasm ${ }^{7}$, emergence of keratinization ${ }^{7}$, epithelial cell morphology 9,14 , epithelial cell size ${ }^{9,11,14}$, presence of inflammatory cells ${ }^{8}$ and cell sheet quality ${ }^{8}$. Tseng ${ }^{7}$ makes use of a slightly different staining protocol to enable him to assess the presence and levels of squamous metaplasia in the specimen. Doughty et all have made specific attempts to quantify CIC specimens in terms of the relationship between cell area and the dimensions and shape of cells obtained. Various studies have been published which have analyzed CIC specimens making use of the above mentioned criteria. CIC has been used to investigate ${ }^{5}$ : the normal ocular surface, dry eye effects, effects of chronic conjunctivitis, impact of contact lenses on the ocular surface, vitamin deficiency, limbal deficiency, presence of micro-organisms, effects of therapeutic interventions, ocular surface neoplasia, keratoconus and the effects of systemic diseases like diabetes, renal failure, thyroid disease and anorexia.

Goblet cell physiology becomes important when trying to understand the underlying pathophysiology occurring in the cells that are observed in CIC. A study investigating in vitro culturing of human goblet cells has shown that epidermal growth factor (EGF) receptors are present in human goblet cells and that proliferation of these goblets cells can be stimulated by $\mathrm{EGF}^{16}$. Is it possible that the absence of EGF can result in a decrease in goblet cell density (for example in contact lens wearers)? The conjunctival epithelium has been shown to be susceptible to the effects of neu- 
rotransmitters and neuromediators in the pathogenesis of mucous hypersecretion, goblet cell hyperplasia and conjunctival hyperreactivity ${ }^{17}$. It has been shown that the basolateral areas of rat goblet cells are surrounded by nerves, probably parasympathetic nerves, that contain vasoactive intestinal peptide (VIP), which were thought to stimulate conjunctival goblet cell mucous production $^{18}$. In a later paper Dartt et al ${ }^{19}$ showed that VIP, released by efferent nerves surrounding the goblet cells can in fact stimulate conjunctival goblet cell secretion. $\mathrm{Ca}^{2+}$ and protein kinase $\mathrm{C}$ have also been shown to play a major role in the cholinergic agonistinduced goblet cell secretion ${ }^{20}$. The interplay between some of the causes of change in the goblet cell population of the conjunctiva (for example contact lenses or dry eyes) and the underlying control of goblet cell secretion is probably complex. CIC can be used to harvest goblet cells so that possible changes can be assessed.

\section{Contact lenses}

Contact lenses are known to produce changes to the normal structure of the conjunctiva. Squamous metaplasia is a term that is commonly used to describe the changes that occur in CIC specimens as a result of contact lens wear ${ }^{7-8,14,21-22}$. Squamous metaplasia is defined as ${ }^{23}$ : "the transformation of psuedostratified ciliated epithelium into stratified squamous epithelium as occurs in certain pathologic conditions" or "reversible change in which one adult cell type is replaced by another cell type" 22 . Tseng ${ }^{7}$ states: "the pathologic transition of a nonkeratinized, stratified epithelium either secretory or nonsecretory, to a nonsecretory keratinized epithelium is called squamous metaplasia. Squamous metaplasia is determined in CIC by the gradual changes that occur in the morphology and density of conjunctival goblet and epithelial cells ${ }^{8}$. Contact lenses result in numerous cellular changes that fall under the squamous metaplasia label: 1 . Snake-like chromatin ${ }^{14,21,24-27}$ : various morphologic nuclear changes occur in squamous metaplasia including pyknosis, two or more nuclei and anisonucleosis. The most frequent alteration of the nucleus is seen as a condensation of the chromatin into a long snake-like or stick-like structure that is aligned with the long axis of the elongated nucleus ${ }^{27}$. 2. Nucleus/cytoplasm (N/C) ratio $^{21,22}$; the size of the nucleus of the cell is compared to the size of the cytoplasm of the cell (overall cell size) as the N/C ratio.
As squamous metaplasia progresses, in this instance as a result of contact lens wear, the $\mathrm{N} / \mathrm{C}$ ratio decreases indicating an increase in the cell size (for example from $1: 2$ to $1: 4)^{21,22,25,26}$. 3. Increased epithelial cell size $22,25,26$ : increases in the size of epithelial cells is a common occurrence in contact lens wear. 4. Goblet cell density ${ }^{14,21-22,24-26}$ : as squamous metaplasia progresses the density of goblet cells decreases to a point where they are often completely absent in the specimen taken from the conjunctiva.

Other changes that occur in CIC specimens collected from contact lens wearers are: 1 .There is greater expression of antigens HLA DR and CD23. HLA DR is an inflammatory marker for immune-mediated inflammatory responses (for example those that occur in giant papillary conjunctivitis) while CD23 is a low affinity receptor for IgE. These changes suggest that contact lens wear has allergic and immune related inflammatory effects on the conjunctiva ${ }^{21} .2$. Decreased expression of three out of five antioxidant enzyme genes occurred in a study investigating the level of antioxidant genes in CIC specimens obtained from soft contact lens wearers. The findings of the study suggest that wearing soft contact lenses might affect the defensive capacity of the conjunctiva against oxidative stress ${ }^{28}$. The cause of the above mentioned changes is thought to be mechanical in nature ${ }^{14,21,27}$. The effects are reversible ${ }^{14}$, not related to the materials used in the manufacture of the contact lenses ${ }^{22,26}$ and are not dependant on the duration of contact lens wear $^{24,25}$.

\section{Dry eye and avitaminosis $A$}

Some controversy exists relating to whether CIC can be used to detect avitaminosis A. Singh et $a^{29}$ and Chowdhury et $a l^{30}$ have provided evidence suggesting that CIC with transfer of cells onto a glass slide can be used as a simplified field technique to detect avitaminosis A. The cellular changes seen were increased epithelial cell size and absent or reduced densities of goblet cells in children suffering from xerophthalmia as a result of avitaminosis A. Rahman et $a l^{31}$, on the other hand, showed that CIC fails to detect changes in the conjunctival structure that were indicative of subclinical vitamin A deficiency. The CIC results were compared to the relative dose response test while the two former groups compared CIC to serum vitamin A levels and plasma retinol concentrations respectively. The different comparisons might explain the disa- 
greement in results.

A study investigating surface bacterial flora in normal and dry eye subjects has shown that both groups have substantial numbers of bacteria present on the ocular surfaces, many of which are considered pathogenic $^{32}$. All subjects were free of any signs of infection. The presence of bacteria in both groups results in a dilemma: do the pathogens result in an inflammatory response and decreased goblet cell density? Is it necessary to intervene in any way ${ }^{32}$ ? Subjects presenting with dry eye signs and symptoms (compared to asymptomatic normals) show a number of common changes in specimens collected by means of CIC. Snake-like chromatin, other nuclear changes, metaplasia, changes in cell size, decreased N/C ratios, and decreased goblet cell density all occurred in dry eye subjects ${ }^{33}, 34$. Keratoconjunctivitis sicca (KCS) also results in a number of changes to the CIC specimen. Increased expression of epidermal growth factor receptors, ErbB2 and ErbB3, occurs as a result of $\mathrm{KCS}$ that is also correlated with ocular surface dye staining. They may also contribute to the abnormal growth and differentiation of the conjunctival epithelium that is usually associated with $\mathrm{KCS}^{35}$. Other CIC changes that occur with KCS are: hyperplasia, hypertrophy, cellular flattening, decreased goblet cell density, snake-like chromatin, and other nuclear changes $^{36-38}$. Some authors ${ }^{36}$ state that CIC should be included in the diagnostic criteria of Sjorgren's syndrome as the procedure correlates well with the presence of the syndrome.

\section{Disease}

Alkaline burns cause a number of changes to the normal CIC picture. Cellular size increases, the N/C ratio decreases and goblet cell density decreases (or becomes zero). Amniotic membrane transplantation following alkaline burns results in quicker recovery to base line findings when compared with conventional medical therapy ${ }^{8,39}$. Uveitis and keratitis both result in no goblet cells being present in the conjunctival specimen. Often there are inflammatory cells as well ${ }^{8}$. CIC specimens obtained from psoriasis sufferers reveal early changes which include squamous metaplasia as well as an increase in goblet cell density ${ }^{40}$. Chronic renal failure patients, when compared with normal subjects, differ significantly. Sixty-six percent of renal failure subjects have grade 3 findings on CIC (severe metaplastic changes are present in the speci- men). The conjunctival changes are not related to the presence of calcium deposits ${ }^{41}$. Acne vulgaris sufferers, who have no ocular involvement, have squamous metaplasia which is thought to accompany the acne ${ }^{42}$. Allergic conjunctivitis is accompanied by numerous CIC changes. Nuclear and well as cytoplasmic changes, anisonucleosis, pyknosis, the presence of cellular debris, polymorphonucleocytes and leucocytes are all present in allergic conjunctivitis sufferers. Decreased goblet cell density is also a common feature ${ }^{10}$. Bacterial and viral infections cause degeneration of epithelial cells with fibrous exudation as well as the presence of micro-organisms ${ }^{10}$.

\section{Drugs}

Markers of inflammation and apoptosis (HLA-DR and TCAM-1) and mucin production (MUC5AC) were used to investigate the effects of preserved and non-preserved Latanoprost and Timolol on conjunctival cells collected by means of CIC. The results of this study show that both Timolol and Latanoprost preserved with benzalkonium chloride produce significantly higher levels of inflammation in the conjunctival epithelium than the non-preserved drugs. It was also shown that the higher the level of inflammation, the lower the goblet cell density. It was revealed that toxicity was mostly associated with benzalkonium chloride and that both Latanoprost and Timolol (to a lesser extent) offer some form of protective effect to the conjunctiva ${ }^{43}$. Oral use of Carbamazepine (Tegretol) has been shown to have conjunctival allergic reaction, conjunctival oedema and conjunctival erythema as side effects ${ }^{44}$. CIC specimens obtained from an individual taking the drug showed a decrease in goblet cell density and squamous metaplasia both of which were attributed to use of the drug ${ }^{45}$. Cyclosporine A has been shown to result in increases in goblet cell density in subjects being treated with the drug for dry eyes. A decrease in epithelial cell turn over was also shown ${ }^{46,47}$.

\section{Keratoconus}

Several studies investigating the presence of lysosomal enzymes in the conjunctivas of keratoconic subjects have been published and/or presented at congresses. Fukuchi et $a l^{48}$ have shown that two lysosomal enzymes, acid esterase and acid phosphatase, are more prominent in the conjunctivas of keratoconic subjects. McMahon et $a l^{49}$ and Shen et $a l^{50}$ have also 
shown that lysosomal enzyme levels are increased in keratoconic conjunctivas making use of CIC. In both reports the feasibility of using CIC (and not surgical biopsy as in Fukuchi et al) for investigating lysosomal enzyme levels in keratoconic conjunctivas was stressed. Goblet cell density decrease and squamous metaplasia were shown to be significantly higher in keratoconic conjunctivas when compared with normal subjects ${ }^{51}$. Both findings were related to the extent of the progression of the keratoconus. In a study investigating the effects of contact lenses on keratoconic conjunctivas Moon et $a^{52}$ showed that the ocular surface changes found in keratoconic conjunctivas was probably as a result of contact lens wear and not necessarily the keratoconus.

\section{Conclusion}

CIC has been shown to have unquestionable advantages: an excellent source of intact and preserved epithelial cells; a non-surgical, minimally invasive, easy, quick and cheap technique, and no side effects ${ }^{5}$. However, a report has been published showing the formation of subconjunctival cyst-like formations following impression cytology ${ }^{53}$. The report also emphasizes the increasing popularity of CIC because of its simplicity, ease of use and applicability to many investigations but does stress the importance of taking care when performing the technique. The cystlike formations were found to be temporary and of not great concern ${ }^{53}$. CIC provides a method of investigating many aspects of ocular surface function that, as far as I can ascertain, have not been taken advantage of in South Africa. There are many questions, both clinical and of a more theoretical nature, that can now be investigated.

\section{References}

1. Warwick R. Eugene Wolff's anatomy of the eye and orbit. London: HK Lewis and Co. 1976.

2. Fine BS, Yanoff M. Ocular histology: a text and atlas $2^{\text {nd }}$ ed. New York: Harper and Row. 1979.

3. Nelson JD, Cameron JD. The conjunctiva: anatomy and physiology. In: Krachmer JH, Mannis MJ, Holland EJ eds. Cornea $2^{\text {nd }}$. Elsevier Mosby: Philadelphia. 2005 37-44.

4. Pfister RR. The normal surface of conjunctiva epithelium: a scanning electron microscope study. Inv Ophthal Vis Sci 197514 267-279.

5. Calonge M, Diebold Y, Sáez V, de Salamanca E, Garcíavázques $\mathrm{C}$, Corrales RM, Herreras JM. Impression cytology of the anterior ocular surface: a review. Exp Eye Res 2004 78 457-472.

6. Haesaert SP. Clinical manual of ocular microbiology and cytology. St Louis: Mosby year book. 1993.

7. Tseng SCG. Staging of conjunctival squamous metaplasia by impression cytology. Ophthalmol 198592 728-733.

8. Adams GGW, Dilby PN, Kirkness CM. Monitoring ocular disease by impression cytology. Eye 19882 506-516.

9. Nelson JD. Impression cytology. Cornea 1988 7 71-81.

10. Divani SN, Margari C, Zikos GA, Papavassiliou GB. Diagnostic impression cytology: a simple technique for the diagnosis of external eye disease. Cytopath 19978 373-380.

11. Doughty MJ. Blades K, Button NF, Wilson G. Further analysis of the size and shape of cells obtained by impression cytology from the exposed portion of the human bulbar conjunctiva. Ophthal Physiol Opt 200020 391-400.

12. DeLellis RA, Faller AT. Cell and tissue staining methods. In: Silverberg SG, DeLellis RA, Frable WJ eds. Principles and practice of surgical pathology and cytopathology Vol 1. London: Churchill-Livingstone. 199743.

13. Stevens A. The hematoxylins. In: Bancroft JD, Stevens A. Theory and practice of histological techniques. Edinburgh: Churchill-livingstone. 1990 109-120.

14. Knop E, Brewitt H. Conjunctival cytology in asymptomatic wearers of soft contact lenses. Graefe's Arch Clin Exp Ophthalmol 1992230 340-347.

15. Vadrevu VLD, Fullard RJ. Enhancements to the conjunctival impression cytology technique and examples of applications in a clinico-biochemical study of dry eye. CLAO J 199420 59-63.

16. Shatos MA, Rios JD, Harikawa Y, Hodges RR, Chang EI, Bernardino CR, Rubin PAD, Dartt DA. Isolation and characterization of cultured human conjunctival goblet cells. Inv Ophthal Vis Sci 200344 2477-2486.

17. Motterle L, Diebold Y, de Salamanca AE, Saez V, GarciaVasquez C, Stern ME, Calonge M, Leonardi A. Altered expression of neurotransmitter receptors and neuromediators in vernal keratoconjunctivitis. Arch Ophthalmol 2006 124 462-468.

18. Dartt DA, McCarthy DM, Mercer HJ, Kessler TL, Chung E-H, Zieske JD. Localization of nerves adjacent to goblet cells in rat conjunctiva. Curr Eye Res 1995 14 993-1000.

19. Dartt DA, Kessler TL, Chung E-H, Zieske JD. Vasoactive intestinal peptide-stimulated glycoconjugate secretion from conjunctival goblet cells. Exp Eye Res 199663 27-34. 
20. Dartt DA, Rios JR, Kanno H, Rawe JM, Zieske JD, Ralda N, Hodges RR, Zoukhri D. Regulation of conjunctival goblet cell secretion by $\mathrm{Ca}^{2+}$ and protein kinase C. Exp Eye Res 200071 619-628.

21. Albietz JM. Conjunctival histologic findings of dry eye and non-dry eye contact lens wearing subjects. CLAO J 2001 27 35-40.

22. Simon P, Saramma G, Sudesh C, Jacob S. Conjunctival impression cytology in contact lens wearers. Indian J Ophthalmol 200250 301-306.

23. Dorland's illustrated medical dictionary $26^{\text {th }}$ edition. Philadelphia: Igaku-shoin/Saunders Co 1981.

24. Anshu MM, Sathe V, Ganar A. Conjunctival impression cytology in contact lens wearers. Cytopath 200112 314-320.

25. Çakmak SS, Ünlü K, Karaca C, Nergiz Y, İpek S. Effects of soft contact lenses on conjunctival surface. Eye Contact Lens 200329 230-233.

26. Tomatir DK, Erda N, Gürlü VP. Effects of different contact lens materials and contact lens-wearing periods on conjunctival cytology in asymptomatic contact lens wearers. Eye Contact Lens 200834 166-168.

27. Knop E, Reale E. Fine structure and significance of snakelike chromatin in conjunctival epithelial cells. Inv Ophthal Vis Sci 199435 711-719.

28. Galarreta DJ, Corrales RM, Herreras JM, Ganzáles MJ, Arranz I, Saez V, Mayo A, Cisneros AB, Calonge M, Chaves FJ. Levels of antioxidant enzyme genes in conjunctival impression cytology specimens from hydrogel contact lenses wearers. Inv Ophthal Vis Sci 200344 E-abstracts 3682.

29. Singh M, Singh G, Dwevedi S, Kumar D, Tiwari A, Aggarwal M. Conjunctival impression cytology in xerophthalmia among rural children. Ind J Ophthalmol 199745 25-29.

30. Chowdhury S, Kumar R, Ganguly NK, Kumar L, Nain CK, Walia BNS. Conjunctival impression cytology with transfer (CICT) to detect pre-clinical vitamin A deficiency among slum children in India. Br J Nutr 199675 785-790.

31. Rahman MM, Mahalanabis D, Wahed MA, Islam M, Habte D, Khaled MA, Alvarez JO. Conjunctival impression cytology fails to detect subclinical vitamin A deficiency in young children J Nutr 1994124 1869-1874.

32. Graham JE, Moore JE, Jiru X, Moore JE, Goodall EA, Dooley JSG, Hayes VEA, Dartt C, Downes S, Moore TCB. Ocular pathogen or commensal: A PCR-based study of surface bacterial flora in normal and dry eyes. Inv Opthal Vis Sci 200748 5616-5623.

33. Murube J, Rivas L. Impression cytology on conjunctiva and cornea in dry eye patients establishes a correlation between squamous metaplasia and dry eye clinical severity. Eur $J$ Ophthalmol 200313 115-127.

34. Rivas L, Oroza MA, Perez-Esteban A, Murube J. Morphological changes in ocular surface in dry eyes and other disorders by impression cytology. Graefe's Arch Clin Exp Ophthalmol 1992230 329-334.

35. Liu Z, Carvajal M, Carraway CAC, Carraway KL, Pflugfelder C. Increased expression of the type 1 growth factor receptor family in the conjunctival epithelium of patients with keratoconjunctivitis sicca. Am J Ophthalmol 2000129 472-480.

36. Rivas L, Murube J, Shalaby O, Oroza MA, Sanz AI. Impression cytology contribution to differential diagnosis of Sjogren's syndrome in the ophthalmological clinic. Arch Soc Esp Oftalmol 200277 63-72.
37. Rivas L, Toledano A, Alvarez MI, Sanz AI, Oroza MA, Murube J. Ultrastructural study of the conjunctiva in patients with keratoconjunctivitis sicca not associated with systemic disorders. Eur J Ophthalmol 19988 131-136.

38. Rivas L, Oroza MA, Sanz AI, Chen Z, Shalaby O, Murube J. The association of conjunctival snake-like chromatin with keratoconjunctivitis sicca. Eur J Ophthalmol 19988 217-223.

39. López-Garcia J, Rivas L, Garcia-Lozano I, Murube J. Analysis of corneal surface evolution after moderate alkaline burns by using impression cytology. Cornea 200625908 913.

40. Söker S, Nergiz Y, Çakmak S, Aytekin S. Conjunctival impression cytology and bulbar surface epithelium changes in patients with psoriasis. Dicle Tip Dergisi 200734 102-106.

41. Dursun D, Demirhan B, Oto S, Pinar A. Impression cytology of the conjunctival epithelium in patients with chronic renal failure. Br J Ophthalmol 200084 1225-1227.

42. Alp BN, Karabas L, Bilen N, Talu H, Kaur A, Yanyali A. Evaluation of ocular surface changes using impression cytology in acne vulgaris. Tr J Med Sci 199929 693-696.

43. Pisella P, Debbasch C, Hamard P, Creuzot-Garcher C, Rat $\mathrm{P}$, Brignole F, Baudouin C. Conjunctival proinflammatory and proapoptotic effects of latanoprost and preserved and unpreserved timolol: an ex vivo and in vitro study. Inv Ophthal Vis Sci 200445 1360-1368.

44. Lawrenson J, Thomson D. Electronic medicine information for optometrists 2008 Thomson software solutions.

45. Doughty MJ, McIntosh M, McFadden S, Button NF. Impression cytology of a case of conjunctival metaplasia associated with oral carbamazepine use. Contact Lens Ant Eye 200730 254-257.

46. Kunert KS, Tisdale AS, Gipson IK. Goblet cell numbers and epithelial proliferation in the conjunctiva of patients with dry eye syndrome treated with cyclosporine. Arch Ophthalmol $2002120330-337$.

47. Pflugfelder SC, De Paiva CS, Villareal AL, Stern ME. Effects of sequential artificial tear and cyclosporine emulsion therapy on conjunctival goblet cell density and transforming growth factor- $\beta 2$ production. Cornea 20082764.

48. Fukuchi T, Yue BY, Sugar J, Lam S. Lysosomal enzyme activities in conjunctival tissues of patients with keratoconus. Arch Ophthalmol 1994112 1368-1374.

49. McMahon TT, Shen JF, Yue B, Sugar J, Cheng EI. Use of impression cytology in keratoconus research. Scientific poster, Poster number 73, American Academy meeting, December 1999.

50. Shen JF, McMahon TT, Cheng L, Sugar J, Yue B, Anderson RJ, Begley C, Zhou J. Lysosomal hydrolase staining of conjunctival impression cytology specimens in keratoconus. Cornea 200221 447-452.

51. Dogru M, Karakaya H, Özçetin H, Ertürk H, Yücel A, Özmen A, Baykara M, Tsubota K. Tear function and ocular surface changes in keratoconus. Ophthalmol $2003 \mathbf{1 1 0}$ 1110-1118.

52. Moon JW, Shin KC, Lee H, Wee WR, Lee JH, Kim MK. The effect of contact lens wear on the ocular surface changes in keratoconus. Eye Contact Lens 200632 96-101.

53. Srinivasan S, Joyce E, Jones LW, Senchyna M. Subconjunctival cyst-like formations following impression cytology. Contact Lens Ant Eye 200528 181-184. 